\title{
SOVEREIGNTY, GLOBAL NORMS AND SECURITY COOPERATION IN SOUTHEAST ASIA
}

\author{
Caleb P. Slayton \\ United States Air Force \\ E-mail: slayton.caleb@gmail.com
}

\begin{abstract}
.
Discussions on cooperative security strategies in Southeast Asia often mention potential threats such as piracy, illegal fishing, terrorism, island disputes and even the security concerns posed by natural disasters. The aforementioned threats are mutual, between not only the ten ASEAN countries but also neighbors, such as Australia and Timor Leste, along with rising and global powers such as China and the United States. However, developing security cooperation even against mutual threats is hindered not only by geographic and monetary restraints but by differences in national ideology, national interests, differing historical perspectives, divergent legal opinions as well as intentional and unintentional misinformation. Using the perspective of a multi-discipline approach to international relations realism and the security dilemma along with highlighting the sources of miscommunication that hinder long-term security cooperation, this paper argues that Indonesia and the US have incorrect and sometimes dangerous perceptions of the other. Differing concepts on national sovereignty, interpretations of international law and the degradation of the rules-based order are all easily manipulated to fuel dangerous misperceptions. Cooperation and sovereignty seem more at odds than ever before. But military cooperation can still be successful using honest assessments that avoid false information and instead pursue sincere engagements.
\end{abstract}

Key words: sovereignty; Indonesia; UNCLOS; defense strategy; security dilemma; security cooperation

\section{KEDAULATAN, NORMA-NORMA GLOBAL DAN KERJA SAMA KEAMANAN DI ASIA TENGGARA}

\begin{abstract}
ABSTRAK.
Diskusi tentang strategi keamanan kooperatif di Asia Tenggara sering menyebutkan potensi ancaman seperti pembajakan, penangkapan ikan ilegal, terorisme, sengketa pulau dan bahkan masalah keamanan yang ditimbulkan oleh bencana alam. Ancaman tersebut adalah saling berkaitan, tidak hanya di antara sepuluh negara ASEAN tetapi juga negara tetangga, seperti Australia dan Timor Leste, bersama dengan kekuatan global yang meningkat seperti Republik Rakyat Tiongkok (RRT) dan Amerika Serikat. Namun, mengembangkan kerja sama keamanan bahkan terhadap ancaman-ancaman timbal balik tidak hanya dibatasi oleh pembatasan geografis dan moneter tetapi juga oleh perbedaan dalam ideologi nasional, kepentingan nasional, perspektif sejarah yang berbeda, opini hukum yang berbeda, serta kesalahan informasi yang disengaja dan tidak disengaja. Menggunakan perspektif pendekatan multi-disiplin untuk realisme hubungan internasional dan dilema keamanan bersama dengan menyoroti sumber miskomunikasi yang menghambat kerja sama keamanan jangka panjang, makalah ini berpendapat bahwa Indonesia dan AS memiliki persepsi yang salah dan kadang-kadang berbahaya dari yang lain. Konsep yang berbeda tentang kedaulatan nasional, interpretasi hukum internasional dan degradasi aturan berbasis aturan semuanya mudah dimanipulasi untuk menyulut kesalahpahaman yang berbahaya. Kerja sama dan kedaulatan tampaknya lebih berselisih daripada sebelumnya. Tetapi kerjasama militer masih bisa berhasil dengan menggunakan penilaian jujur yang menghindari informasi palsu dan malah mengejar keterlibatan yang tulus.
\end{abstract}

Kata kunci: kedaulatan; Indonesia; UNCLOS; strategi pertahanan; dilema keamanan; kerja sama keamanan

\section{INTRODUCTION}

Discussions on cooperative security strategies in Southeast Asia often mention potential threats such as piracy, illegal fishing, terrorism, island disputes and even the security concerns posed by natural disasters. The aforementioned threats are mutual, between not only the ten ASEAN countries but also neighbors, such as Australia and Timor Leste along with rising and global powers such as China and the United States. However, developing security cooperation even against mutual threats is hindered not only by geographic and monetary restraints but 
by differences in national ideology, national interests, differing historical perspectives, divergent legal opinions as well as intentional and unintentional misinformation. The factors that influence and challenge Indonesian and American security cooperation include all of the above.

Parsimonious international relations theories do not always consider the complex political, economic, historical and even psychological environment that leads to misperceptions of strategy not only between partner nations, but also allied ones. Robert Jervis is well known for advancing a multi-discipline approach to international relations realism and the security dilemma while highlighting the sources of miscommunication that hinder long-term security cooperation.

This paper will begin with a theoretical discussion on Indonesian-US security cooperation citing recent scholar reflections on Robert Jervis' work. Second, the essay will briefly outline US military activities and history in East Asia along with Indonesia's security priorities. In addition to theory on security cooperation in general, the author applies key research findings from studying and observing Indonesian military strategy as a Sekolah Staf dan Komando Angkatan Udara (SESKOAU) student throughout the 2018 academic year. This paper is made possible by the openness of Indonesia's highest military academic institutions and its graciousness as a host and partner.

This paper argues that Indonesia and the US have incorrect and sometimes dangerous perceptions of the other most often caused by poor security analysis. Overall, differing concepts on national sovereignty, interpretations of international law and the degradation of the rules-based order are all easily manipulated to fuel dangerous misperceptions. The security examples and approach used in this paper were selected to address some of the most frequent topics of discussion in the SESKOAU classrooms and lecture halls, which are themselves preoccupations of Indonesia's military headquarters.

Robert Jervis' writings on the security dilemma and security cooperation have been re-read, analyzed and updated for decades. Editor James Davis' 2013 contribution combines a number of security scholars from different disciplines to discuss the continuing merit and contemporary application of Jervis' arguments. The security dilemma claims that when one country increases its military posture, neighboring countries, regardless of diplomatic relations are compelled to do the same. However, Jervis contends that certain types of military actions and equipment build-up that is defensive in nature, need not always signal an offensive intent.

At the same time, defensive realists often maintain that the, "Intentions and preferences of others" cannot be known for certain. In this global anarchic environment, perceptions and misperceptions are the main hurdles to cooperation and drivers of insecurity (Snyder, 2013: 14). The complex system of interaction, perception and mis-communication is made worse through the use of and claims to guile and deception. Even if cultural, political and economic conditions in a multi-discipline understanding of security do influence cooperation, there are also universal human factors, temptations to biases, "cognitive shortcuts" that we all use to miscalculate the dangers of a potential adversary while at the same time underestimating our own ability against it (Snyder, 2013: 17).

The condition above, while not a cohesive theory, can be summarized as follows, "Under conditions of complexity and uncertainty, people operate according to the "cognitive miser" model, using devices such as rigid belief systems, cognitive biases, heuristics, and other shortcuts to simplify one's choice and assessment (Schweller, 2013: 27)." Crosscultural engagements in different languages, different historical experiences, different national ideologies and foreign relations strategies combined with what constructivists call created national identities create an environment ripe for misperception and unintended conflict. How can the Indonesian-US security cooperation environment avoid these pitfalls?

Table 1. Comulative U.S. troop deployments by region and decade

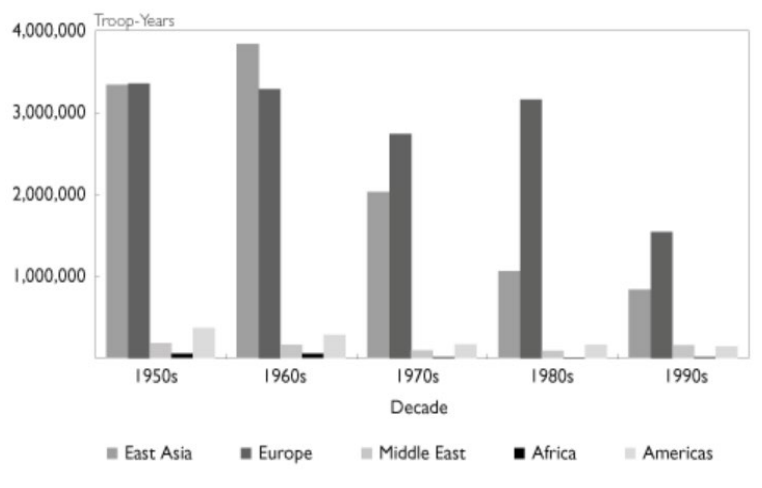

Source: The Heritage Foundation 
Let us first take history into account. The US military as an expeditionary global force is fundamentally different than militaries that are largely defensive in nature. On the opposite spectrum of the expeditionary force concept are militaries contained by foreign policies of nonintervention, as is Indonesia's military (TNI). The US military presence in East and Southeast Asia is not a recent or sudden development. The US military posture is largely influenced by the aftermath of WWII. The most US military personnel ever deployed overseas in a year occurred in 1968, a total of 1,082,777 personnel. At the US military's lowest overseas presence in 1999, 206,002 personnel were deployed (Kane, 2003). Since this 2003 data set, military personnel deployments continue to experience a downward trend.

The East Asian perspective is important because as the US military continues to draw down its troops overseas, closing 22 units in Germany and three in Italy, East Asian military numbers remained relatively the same (Feickert, 2014). A 2013 Rand study concluded that the US is best served with a smaller military footprint, more agile, more advanced, able to react quickly against threats to US interest while awaiting assistance from partners, allies and additional airsea lift of US troops (Lostumbo et al, 2013). US military presence in places like Korea and Japan factor into the host nation's defense capabilities. Currently, there are roughly 154,000 US troops in Asia, including five aircraft carrier strike groups (Glaser, 2017).

Recent US troop drawdowns mean that the US military can be more efficient and flexible but also means that it relies on allies and partners for access. The US posture, in short, requires greater cooperation. This cooperation is reflected in a US military rotational presence in places like Darwin Australia, the Philippines and Singapore. As mentioned by the 2013 Rand study, "The United States is trying to increase the level and sophistication of activities with those countries and other regional partners." In terms of security priorities, Southeast Asia still falls below the Korean Peninsula and treaty obligations to Japan. The 2018 National Defense Strategy, however, signal an important development.

The 2018 US Defense Strategy begins by stating that the long-standing rules-based international order is crumbling. This rulesbased or norms-based order includes respecting customary international law of the seas. At least since 2001, the US has cited international terrorism as the main global threat. However, the new US Defense Strategy states that "Interstate strategic competition", is the primary contemporary security challenge, naming China and Russia. The security cooperation the US seeks in Southeast Asia is meant to directly decrease the military and even economic influence of China in the region; to prevent the spread of China's authoritarian ideology and regional hegemony. In addition, the US, as opposed to China, rallies for transparency in the peaceful resolution of East Asian disputes.

Such a "complex global security environment" is ripe for misperception according Jervis's theoretical arguments. Ironically, while the condition makes cooperation more difficult, cooperation itself increases in priority. The military posture in the 2018 Defense Strategy states as its objective, "Defending allies from military aggression and bolstering partners against coercion, and fairly sharing responsibilities for common defense".

Tyson Wetzel of the US Air Force explains that from a national, US military perspective, the "Dynamic Force Employment" concept in the 2018 Defense Strategy will be difficult to execute (2018). It calls for less predictable deployment locations and timetables which make unit and individual preparedness a physical and emotional challenge. Tyson provides the example of three agile carrier fleets, sailing between the Indian Ocean, South and East China Seas with scant forewarning before changes in direction. The military presence is meant to assure allies and deter Chinese aggression, signaling that the US is ready for any contingency. However, their main purpose is peace, stability and a rulesbased order.

Asidefromtheinternalmilitarypreparedness challenge, the Dynamic Force Employment concept, despite an emphasis on partner and ally support, according to Jervis's foundational ideas, is extremely challenging in terms of cooperation. Each partner and ally have their own political, cultural and historical influences that make such dynamic forms of cooperation a foreign policy behemoth. Indonesia is a prime example.

\section{METHODOLOGY}

This paper builds on a literature study procedure that emphasizes contemporary security discourse in the Southeast Asian 
region, especially Indonesia. The analytical perspective used in this paper is taken from the construction of the theory of international relations realism and the shared security dilemma that was built by Robert Jarvis. Most of the data taken come from documents that reveal the distribution of the placement of US troops in Southeast Asia which is then compared to similar documents from the Indonesian version. The effort aims to examine areas that allow ongoing miscommunication between countries, thus causing dangerous misperceptions.

\section{DISCUSSION}

\section{Indonesia's Security Priorities}

The 2018 Defense Strategy states that, "Today, every domain is contested - air, land, sea, space, and cyberspace." Meaning, US will face stronger resistance in deploying where and when desired. Indonesia's specific interpretation of UNCLOS (United Nations Convention on the Law of the Sea) is directly involved in this growing concern. Indonesia's 17,000 islands and atolls have been declared an archipelagic state, which according to Elson (2009), is one more step in Indonesia's project of identity creation. Indonesia's internal security depends on unity between hundreds of people groups and languages, bound in a national language and ideology, Pancasila.

This author has argued in other publications (Slayton, 2018) that Indonesia's military also deeply fears foreign meddling in the form of hybrid, irregular warfare; intent on purposely disrespecting Indonesia's sovereignty and gaining access to its resources. Indonesia's sovereignty project has expanded to declare Indonesia as a maritime fulcrum, writing policy and government directives defining not only archipelagic borders but strict waterway and airspace regulations above land and on water. Indonesian Air Defense Command claimed that in 2015 there were over 140 violation of Indonesian air space, the majority of them committed by US military and civilian aircraft ("Sepanjang 2015 ada 140 pelanggaran udara"; 2015, 8 Dec).

As scholar Evan Laksmana argues (2018), the main concern against Indonesia's recent air space regulations and even a number of their UNCLOS interpretations as applied to sea lanes, is that they have been unilateral decisions. There was little to no advance notice or negotiation with Indonesia's neighbors, or the United States, against whom the most airspace violations are registered. The latest 2018 Air Space Regulation itself has yet to be translated into English by the Indonesian government.

If Indonesia is primarily concerned about its archipelagic identity and national sovereignty, how does that align with US concerns on China's pursuit of regional hegemony? China's nine dash line does not extend to Indonesia's northern most island, Natuna. However, it does reach into Indonesia's exclusive economic zone (EEZ) which according to UNCLOS extends out to 200NM beyond a country's borders.

President Obama's US pivot (now called rebalance) to Asia did "dovetail" with President Jokowi's aspirations for a Global Maritime Fulcrum(Harding \& Natalegawa, 2018). The clash is about power projection but also interpretations of sovereignty, definitions of UNCLOS and the complex competitive economic environment. The mutual interest of all remains the same, a peaceful resolution of disputed island claims and a mutual respect of individual EEZs.

\section{Jervis in Relation to ASEAN}

The US Defense Strategy doesn't simply balance power, it balances a specific threat. The 2018 strategy calls for the, "Free and open access to common domains" with obvious reference to South China Sea (SCS) waters but also more liberal interpretations of Indonesia's sea lane and airspace regulations, at least until multilateral negotiations can come to a mutual agreement on such a global strategic location. ${ }^{1}$ In addition, Indonesia's foreign and military posture is fundamentally different than that of the US. Indonesia is a founding member of the Non-Aligned Movement (NAM) which eschews alliances and military coalitions, claiming their propensity for stirring up aggression.

The US has been a key Indonesian partner since its declared independence in 1945 even if its people-to-people and historical interactions have not been as strong as that of the US with South Korea, Japan, Philippines or Thailand. In the US National Security Strategy (2017), the US seeks to strengthen its maritime security partnerships specifically with Indonesia, Vietnam, Singapore

Indonesia's airspace and waterways are more crucial to international access than say, US air space. The US ADIZ that surrounds its compact land masses can in now way be compared to the island spread of Indonesia. Indonesia's archipelago and the potential of a declared ADIZ should not be compared to the US example. 
and Malaysia; all partners, not US allies. In 2010, US President Obama and Indonesian President Susilo Bambang Yudhoyono signed a comprehensive partnership to create closer Indonesian-US government and economic ties. That partnership was upgraded to a strategic partnership in 2016.

Despite this partnership language there are a few key people-to-people programs that are severely lacking. "Education exchanges are miniscule" states a recent CSIS report (Harding \&Natalegawa, 2018). The same reporthighlights over 170 annual bilateral military-to-military engagements between the US and Indonesia. But without quality culture and language understanding between the two, it is very easy to misinterpret strategy and intent. Indonesia is deeply suspicious of regional coalitions like the Five Power Defense Arrangement between Malaysia, Singapore, Australia, New Zealand and Britain (Dobell, 2018) and even wary of security dialogues like the Quadrilateral Security Dialogue between the US, India, Australia and Japan (Harding \& Natalegawa, 2018). The US cannot simply console Indonesia by explaining that its fears are unfounded.

Indonesia and even China fire back at the US by asking why the US has not ratified UNCLOS, even though it still abides by international norms. During the US Senate ratification process, some senators supported UNCLOS saying that it complied with the US concept of EEZs and could provide legitimacy to the US in resolving SCS disputes. Senators against UNCLOS ratification claimed that China also argues its rights according to UNCLOS which means that there is still not a universal interpretation of UNCLOS standards (O'Rourke, 2018). Indonesia's own interpretations of UNCLOS in relation to its sea

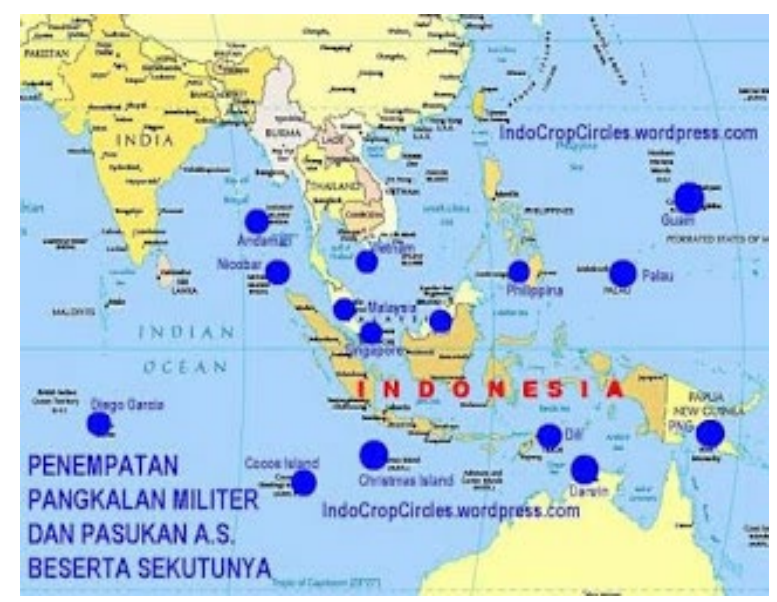

Picture 1. Location of US Personnel and Bases along with Allies lanes and archipelagic waters clash with almost all of its neighbors and the US. ${ }^{2}$

Clashes of interpretation then lead to an increased perception of threat. Indonesia's sovereignty argument sits at the core of Indonesia's security conc erns and manifests itself in alarming ways within Indonesia's military strategic statements and military education curriculum. Images like the one on the left would normally be dismissed as inflammatory news or at least amateur analysis. However, since this very image is frequently shown in the lecture halls of Indonesia's highest military education facilities and discussed on Indonesian military blogs it needs to be mentioned. ${ }^{3}$

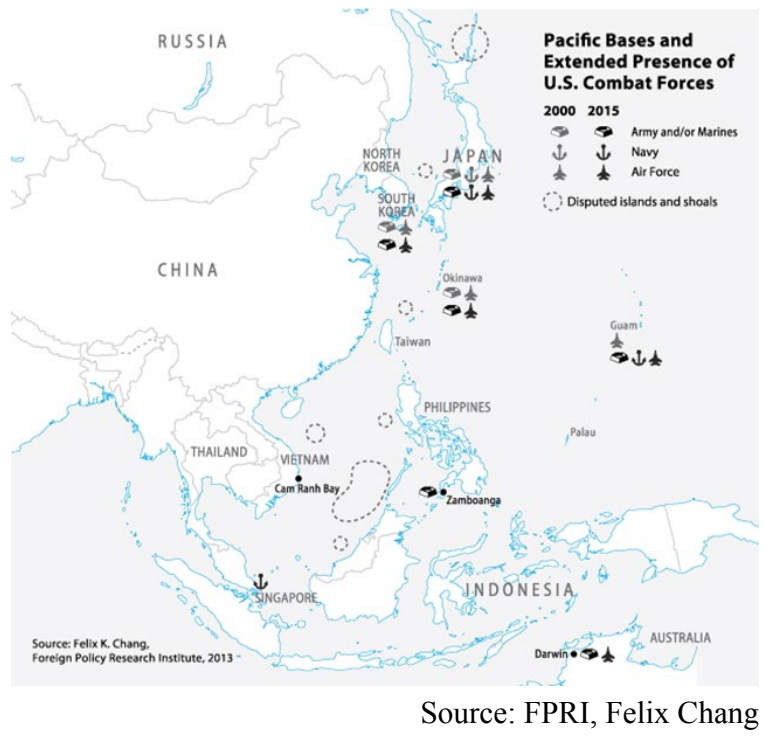

Picture 2. Pasific bases and extended presence of U.S combat forces

The original map source on this example is a website of conspiracy theories to include discrediting the 9/11 Twin Towers attacks and confirming sightings of UFOs. But like other hoax news, the source information evolves. The map initially titled "US Personnel" or "Training Exercise location" is overgeneralized to become "US Military Base" which is not only purposely misleading but dangerously incorrect. The most troubling of these news sites while reminding its readers to reject hoax news because it only serves to divide Indonesia's peoples and draw a wedge between its people groups, then continues by encouraging readers to instead look at the foreign threats, quoting national leaders who

\footnotetext{
${ }^{2}$ For example, Indonesian policy has no horizontal, east-west sea lanes across its archipelago but instead only three vertical, north-south passages.

3 Examples can be found at: http://satoetoedjoehdelapan.blogspot.com/2016/06/gawat-indonesia-dikepung-15-pangkalan. $\mathrm{html} \& \mathrm{https}: / /$ newsstatusaceh.wordpress.com/2015/12/30/indonesia-dikepung-15-pangkalan-militer-asing/ \& http://www.batasnegeri. com/danrem-ingatkan-ancaman-asing-di-wilayah-perbatasan/
} 
themselves believe that "Indonesia is surrounded by the US military" for the possible purpose of invasion.

The map to the right is a better illustration of the US's military presence in Southeast Asia. It does not selectively depict US cooperation in order to create the appearance of a US imminent invasion of Indonesia. The inflammatory maps and blog spots also conveniently ignore the 170 mil-to-mil engagements between Indonesia and the US, which, if included, would clearly show Indonesia as a partner in Southeast Asia instead of a target.

The historical, military and political complexity evident in Jervis's ideas have a strong influence on security cooperation challenges in Southeast Asia. The economic perspective is no less challenging, as the recent US-China trade war makes evident. Again, referencing viral news and military blog spots, the graphic below was shown no less than ten times during Air Force Command and StaffCollege lectures, by civilian and military lecturers alike.

The graphic combines economic cooperation with Indonesia's concern for sovereignty. The graphic claims in the title that oil, gas and other mining locations are land owned by foreign entities. The more disparaging blogs and news sources, along with the Command and Staff College narrative, is that Indonesia's wealth is not only being controlled by foreign companies but they are encroaching on Indonesia's land sovereignty; an economic and security threat of the highest order. ${ }^{4}$

In the disparaging narrative, rarely is it mentioned that the data was from 2012. Even though $50 \%$ of the map's data is obsolete, this 2012 version is what remains in the 2018 blogs, news and school curriculum. There was never a discussion on the origins of each business agreement nor of the benefit and profit in the form of taxes, technology transfers or development projects that these cooperation agreements create. According to the US Embassy in Jakarta, as an example, the cooperation project in Cepu paid \$44 billion in taxes. Exxon alone has donated more than $\$ 30$ million in community projects. The Indonesian Minister of Energy and Resources has called American companies the most innovative in Indonesia. These American energy companies are also 95\% Indonesian staffed.

While this second graphic went even more viral than the first one mentioned, there were credible Indonesian news sources that tried to correct the misinformation. Auliani of Kompas News (2016) interviewed high ranking officials who were able to dispel the rumor of "foreign

${ }^{4}$ Examples can be found here: https:/www.faktajabar.co.id/soal-indonesia-bubar-begini-wanti-wanti-gatot/ \& https://asiswanto.net/?page_id $=312$

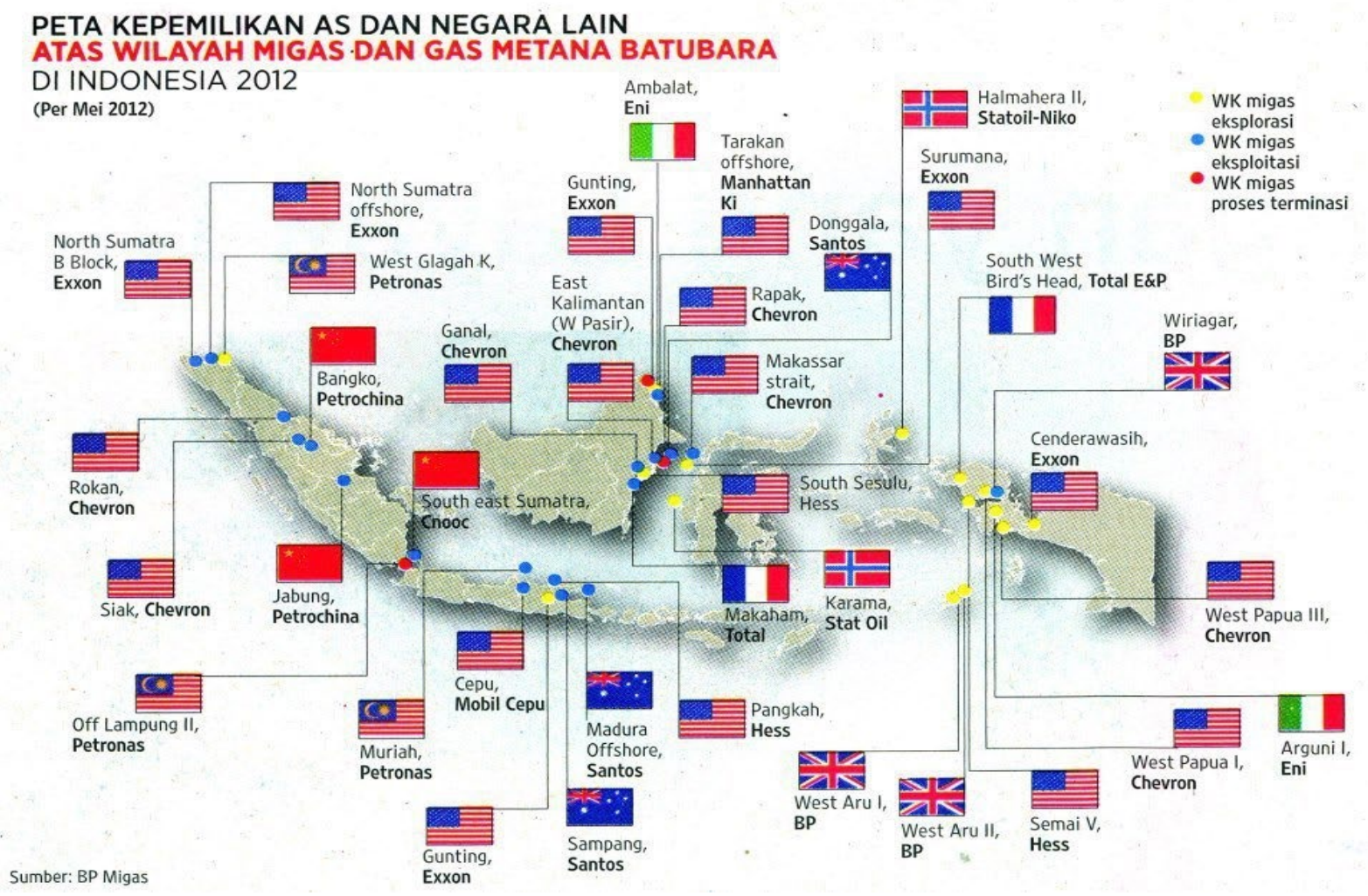

Picture 3. U.S and other states owned oil, mineral, and gas fields in Indonesia 
land ownership" and the raping of Indonesian wealth. The most important item to mention is that the vast majority of Indonesia's gas and oil fields are Indonesian owned, none of which is depicted on the map.

Cooperation takes at least two sides. Beyond the US's new defense strategy that could easily exacerbate the challenge to cooperation, US news outlets and the general American public have a myopic vision of Indonesia or are completely ignorant of the strategic partner all together. US and international news outlets routinely carry themes such as religious persecution, natural disasters, terrorism and human rights violations as valid descriptions of Indonesia's people and identity.

These historical, political and economic interpretations have a direct influence on the success or failure of cooperation. The IndonesianUS context is exactly the complex environment that Jervis describes as ripe for unintentional misunderstandings.

\section{Challenges for ASEAN Region Cooperation}

Indonesia's military policies are trending towards tighter sovereignty regulations while the US's deployment activities to East and Southeast Asia become more unpredictable. Many commentators, including Tyson Wetzel quoted previously, make it clear that the US needs to communicate its strategy clearly with treaty partners such as South Korea, Japan, Australia, Thailand and the Philippines. Partner countries like Vietnam and Singapore will also be keen to understand how the US's new defense strategy will affect US military training cooperation and port calls in their naval installations. But what has not been mentioned as frequently is the 2018 Defense Strategy's impact on Indonesia, a strategic partner.

Indonesia may not see China's influence in the same fashion as the US does. Indonesia's own record in combined military operations is scant. According to Ely Ratner (2013), if the US pushes its allies and partners too hard against China, the US could lose support from those same partners. If US partnerships are seen as merely a "Trojan horse" against Chinese influence, then the US will no longer be perceived as a sincere cooperation partner. Cooperation in Southeast Asia is a mismatch of perceptions both economic and ideological. Indonesia is not the only country in the South China Sea waters seeking to increase sovereignty rights into the EEZs. China,
Vietnam, Thailand, Malaysia and Cambodia all have different strategies and interpretations of UNCLOS.

The complex security environment brings in a psychological influence that manifests itself differently from one state to the next. Scapegoating is a common strategy between disputing countries and the US is a common target. Because Southeast Asia has been the target of some of the most damaging forms of statecraft and deception in the past, super powers like the US are not always trusted at face value. Too often, bureaucratic, diplomatic and administration mistakes made by US officials are not seen as mistakes but instead calculated tactics. The US gets too much credit for always doing what it means to do. This means one crucial piece to any relationship, apology and reconciliation, is almost impossible without at least minor retribution.

It would seem that in the complex environment of Jervis's perception and misperception, politics loses the ability to accept and give a sincere apology. For that, we are all at fault.

\section{How to overcome the Challenge?}

The 2018 National Defense Strategy offers these suggestions in maintaining good cooperation with partners: giving a clear and consistent message to partners and modernizing partners to better synergize with US equipment. Another message that needs to be sent and received clearly is how the US intends to use its foreign bases and access. Foreign basing and partner nation access have been statistically proven to increase military cooperation and build more cohesive multinational military capabilities for all involved. "Forces based overseas benefit from the interoperability and adaptability skills and the greater cultural awareness gained from more frequent training with foreign partners. These skills are also important for U.S.based forces to develop through rotational and temporary deployments (Lostumbo et al., 2013)."

Foreign basing and rotations greatly enhance partnerships, cooperation and mutual understanding. Even if Indonesia is not a host to long-term US troop rotations, they benefit from US rotational presence in Singapore, Thailand, Philippines, Australia and other seafaring units, because they make possible more frequent milto-mil engagements and more robust multilateral exercises with Indonesia. 
If US partners like Indonesia are hearing the US military's clear strategy for foreign deployments and rotating Southeast Asian presence, they are either not listening or not fully buying the argument. This is disconcerting considering the 170 mil-to-mil engagements last year alone with Indonesia which apparently are not enough to break through the cultural barriers and strategic misperceptions. Those same 170 engagements would not have been possible had the US not had its rotating East Asian and ASEAN region presence.

Perhaps it is not just mil-to-mil engagements that break through the "fog of shared misperceptions" but longer, more culturally immersed military exchange tours (Snyder, pg. 22). Since the 1950s, thousands of Indonesian officers have attended training in the US. Fifty officers by 2015 had enrolled in 34 US education programs (Laksmana, April 2018). The rate of US officers on long-term education programs in Indonesia does not fare nearly as well. In the last ten years, the US has sent an Army officer to the Indonesian Army Command and Staff School almost every year while an Air Force and Navy officer rotate every other year in attending their respective Indonesian Command and Staff Schools. Those are the same officers, with a few exceptions, that return to staff the US Embassy Security Cooperation Office in Jakarta and Cooperation and Analysis desks in Indo-Pacific Command, Hawaii. One could argue that Indonesia's military knows far more about the US than the US military knows about Indonesia.

While the US strategy will require sincere and clear diplomacy in order to maintain its Southeast Asian partnerships, Indonesia would benefit from Jervis's advice on choice of military weapons (Snyder, pg. 21). Offensive weapons must be clearly distinguishable from defensive weapons. The most advanced weapon may not only be ineffective in ensuring national defense but could be misperceived by a neighbor as a military escalation. Even if Southeast Asia is not in danger of starting a weapons race (Laksmana, March 2018) as countries like Indonesia replace old and obsolete military equipment, they could take a lesson from Taiwan.

Taiwan's latest defense strategy is not to out-number or out-modernize China using the latest US technology. Advanced US weapons suites, including the F-35, are, "expensive, designed to project power over great distances, and maximize mobility and networks to take the fight to the enemy with overwhelming superiority". Taiwan, instead, is employing an irregular warfare strategy meant to withstand attacks in a layered defense. Taiwan is also assured US military assistance under the Taiwan Relations Act of 1979 should China pursue military invasion of Taiwan instead of mutual political agreement in order to unite the two (Thompson, 2018).

Indonesia's military acquisitions program must consider not only its domestic production capabilities but also a prudent, realistic and effective foreign acquisitions program that follows the logic framework of a cooperative defense plan. An extremely interesting dynamic unfolded in the Command and Staff School lecture hall when visiting Navy Captain (Colonel) Ganif Deswantoro (2018, 15 May) asked rhetorically if Indonesia needed (perlu) an aircraft carrier. As if in rehearsed unison, the 120 Indonesian students shouted "Perlu!" (Yes, we need it). Three short weeks later, another civilian visiting lecturer asked the same question. Without waiting for a response, he answered that the aircraft carrier is an offensive weapon; only aggressive superpowers buy aircraft carriers (Leonard, 2018, 7 June). This vignette aside, Southeast Asian countries do need to consider more than the most recent technology for their military upgrades. And it makes a big difference whether or not one can depend on a military partner or ally when your sovereignty is actually under threat.

According to Evan Laksmana, Indonesia does have a diverse line of weapons suppliers from 32 different countries (18 April 2018). However, what it does not yet have is a defense policy based on a coherent strategy, especially when it comes to Indonesia's UNLCOS interpretation of air space regulations.

The US needs to better understand the position of its partners, their culture and politics. US strategy, regardless of mutual threat, cannot simply expect or take for granted security cooperation. Diplomatic meetings rarely translate to solid cooperation and in the case of IndonesiaUS relations, too much of their interaction is based on bureaucratic ritual. As Harding \& Natalegawa recently confirmed between the US and Indonesia, "Official interaction is often bureaucratic and rarely strategic."

Finally, not all bureaucratic, administrative or diplomatic mistakes are done on purpose. Jervis referred to the difference between "hot 
cognition" and "cold cognition", similar to motivated and unmotivated bias. Motivated bias stems from emotion and poor analysis. Unmotivated biases, "Were assumed to constitute a form of mistake" (McDermott, pg. 50). In the most challenging of environments, "Deception is so normal in international politics that policy-makers always look for the hidden meaning (Mercer, pg. 64)." This psychological complex diplomatic environment makes for extremely difficult security cooperation where one mistake, unintended, is perceived as intentional by the partner, who then either moves to exact diplomatic punishment or creates temporary cooperation barriers to restore the dignity of its perceived slight to sovereignty.

The US 2018 Defense Strategy of quick reaction, unannounced deployments and sudden military projects, especially throughout Southeast Asia could easily exasperate the security cooperation challenge mentioned in this essay, despite the fact that the Defense Strategy hinges on the very participation of Southeast Asian allies and partners.

\section{CONCLUSION}

Differences in culture, history, language and above all, a lack of quality analysis means that what is perceived as a clear signal by the sender can be unclear and confusing to the receiver (Mercer, pg. 71). Indonesia's expanding concept of sovereignty, in the form of new air space policies, for one, combined with their non-aligned (NAM) foreign policy and noninterventionist intentions can all too easily clash with America's developing concept of defense projection. It doesn't help that diplomatic engagements between US leaders and East and Southeast Asian leaders leave many strategic cooperation questions unanswered.

It is regrettable and even dangerous how influential false news and biased reporting can be on military and civilian populations in both the US and Southeast Asia. Military professionals, especially, must be armed with analysis skills that are not dominated by emotions and can be groomed in the lecture halls of quality military and civilian institutions.

Jervis's description of the complex military cooperation environment that incorporates history, economy, politics and psychology explains the Southeast Asian condition. In this environment, selective bias is extremely tempting and it makes signaling all the more difficult. The US's primary approach must prioritize and never underestimate sincere communication.

Finally, expanding concepts of sovereignty are exacerbated by the growing violations and divergent interpretations of international norms. When states need cooperation the most, the environment appears least conducive for it. Only honest analysis and consistent, clear communication built on strategy-based policies can avoid dangerous misperceptions.

Disclaimer: The views and opinions expressed in this essay are the author's own and do not represent the policy or views of the United States government.

\section{REFERENCE}

Auliani, P.A (2016, 24 Aug). Asing Kuasai Migas Indonesia?. Kompas. Accessed on 6 October 2018 from: https://ekonomi. kompas.com/read/2016/08/24/112344726/ asing.kuasai.migas.indonesia

Chung, F. (2013). Sideways: America's Pivot and its Military Bases in the Asia Pacific. Foreign Policy Research Institute. Accessed on 2 October 2018 from: https://www.fpri.org/ article/2013/04/sideways-americas-pivotand-its-military-bases-in-the-asia-pacific/

Davis, J. ed. (2013). Psychology, Strategy and Conflict: Perceptions of Insecurity in International Relations. Routledge

Deswantoro, G. Kol Laut (15 May 2018) Ceramah "Doktrin TNI AL" di Sekolah Staf Dan Komando Angkatan Udara

Dobell, G. (2018) The durian pact: the Five Power Defence Arrangements. Australian Strategic Policy Institute. Accessed on 6 Oct 2018 from: https://www.aspistrategist. org.au/durian-pact-five-power-defencearrangements/

Elson, R.E. (2009). The Idea of Indonesia: A History. Cambridge University Press

Feickert, A. (2014). Army Drawdown and Restructuring:

Background and Issues for Congress. Congressional Research Services

Glaser, J. (2017). Why Bulking Up the US Military Presence in Asia Is a Bad Idea. The CATO Institute 
Harding, B. \& Natalegawa, A(2018). Enhancing the U.S.-Indonesia

Strategic Partnership. Center for Strategic and International Studies

Hutabarat, L. (7 June 2018) Ceramah "Kawasan Amerika" di Sekolah Staf Dan Komando Angkatan Udara

Kane, T. (2003). Global U.S. Troop Deployment, 1950-2003. The Heritage Foundation. Accessed on 2 October 2018 from: https:// www.heritage.org/defense/report/globalus-troop-deployment-1950-2003

Laksmana, E. (2018). Is an Indonesian Air Defense Identification Zone forthcoming? Asia Maritime Transparency Initiative. Accessed on 2 October 2018 from: https://amti.csis.org/indonesian-adizforthcoming/

Laksmana, E. (2018, March). Is Southeast Asia's Military Modernization Driven by China? It's Not That Simple. Global Asia. Accessed on 6 October 2018 from: https:// www.globalasia.org/v13nol/cover/issoutheast-asias-military-modernizationdriven-by-china-its-not-that-simple evan-a-laksmana

Laksmana, E. (2018, 18 April). Are military assistance programs important for US-Indonesia ties?. East Asia Forum. Accessed on 2 October 2018 from: http:// www.eastasiaforum.org/2018/04/18/aremilitary-assistance-programs-importantfor-us-indonesia-ties/

Lostumbo, M. (2013). Overseas Basing of U.S. Military Forces An Assessment of Relative Costs and Strategic Benefits. The Rand Cooperation.

McDermott, R. (2013) “Political Psychology” from Davis, J. ed. (2013). Psychology, Strategy and Conflict: Perceptions of Insecurity in International Relations. Routledge

Mercer, J. "Rational Signaling Revisted" from Davis, J. ed. (2013). Psychology, Strategy and Conflict: Perceptions of Insecurity in International Relations. Routledge
“US National Defense Strategy”. (2018). United States Department of Defense

"US National Security Strategy". (2017). The White House

O'Rourke, R (2018). China's Actions in South and East China Seas: Implications for U.S. Interests-Background and Issues for Congress. Congressional Research Services

Ratner, E. (2013). Rebalancing to Asia with an Insecure China. Washington Quarterly, $36,2,21-38$

Sepanjang. (2015) ada 140 pelanggaran udara (2015, 8 December). Antara News. Accessed on 2 October 2018 from: https:// www.antaranews.com/berita/533951/ sepanjang-2015-ada-140-pelanggaranudara

Schweller, R. (2013) "Jervis's Realism" in Davis, J. ed. (2013). Psychology, Strategy and Conflict: Perceptions of Insecurity in International Relations. Routledge

Slayton, C. (2018). War-gaming Scenarios: a reflection of foreign policy and the perceptions on which it is based (Indonesia as a case study). War on the Rocks, in editing process for publication.

Snyder, J. (2013). "Both Fox and Hedgehog" in Davis, J. ed. (2013). Psychology, Strategy and Conflict: Perceptions of Insecurity in International Relations. Routledge

Thompson, D. (2018). Hope on the Horizon: Taiwan's Radical New Defense Concept. War on the Rocks, accessed on 6 October 2018 from: https://warontherocks. com/2018/10/hope-on-the-horizontaiwans-radical-new-defense-concept/

Wetzel, T. (2018). Dynamic Force Employment: A Vital Tool in Winning Strategic Global Competitions. The Strategy Bridge. Accessed on 6 Oct 2018 from: https:// thestrategybridge.org/the-bridge/2018/9/18/ dynamic-force-employment-a-vital-tool-inwinning-strategic-global-competitions 